\title{
THE EARNINGS GAP AND PAY EQUITY: DEVELOPMENTS IN FIVE COUNTRIES
}

\author{
Prue Hyman \\ Victoria University of Wellington
}

International variability in both the extent of the average female-male eamings gap and its pattern of change in the last few decades is considerable. The types of measures adopted, for equity and/or efficiency reasons, to improve the position of women in the paid labour force also vary. The pervasiveness of horizontal (and to a slightly lesser extent, vertical) occupational segregation by gender and ethnicity is a more common thread, but the degree to which this is responsible for the earnings gap is less certain. To throw some light on international differences in experience and policy, a thorough examination is needed of the various legal, administrative, industrial relations and ideological frameworks governing the labour markets, and the wider economic and social contexts. This paper attempts to take a small step in this direction by briefly discussing pay equity initiatives in five countries, Australia, Canada, Great Britain, New Zealand and the United States. The justification for pay equity within initiatives towards gender equality is, of course, controversial. Even among feminists, positions depend on perspectives (oversimplistically, liberal, feminist or socialist), and with assessments of which groups of women, if any, may gain to what extent from pay equity successes (Acker 1989, Bose and Spitze (eds) 1987, Brenner 1987, Cuneo 1990, Evans and Nelson 1989, Hartmann (ed) 1985, Reskin 1988). To those economists and policy makers who believe that the labour market either does, or can and should, be made to work in a competitive manner, pay equity measures are anathema

In this paper, I define the major terms then briefly outline the pay equity initiatives taken in each country. I then discuss the use of lower levels or more rapid rates of decrease of the female male earnings gap as proxies for less gender discrimination in the labour market. The relative importance of pay equity developments, summarised into typologies, as against economic and political climates for success, is then assessed. A final section speculates on the future of the earnings gap and pay equity in New Zealand and suggests where future research is most needed.

\section{Major Terms}

Three major terms are used in this area, equal pay for work of equal value, comparable worth, and pay equity. The question of whether they have the same meaning has been controversial, particularly in Australia (Australia Conciliation and Arbitration Commission 1986, Hyman
1987). Shifts between them have been partly a question of strategy and politics. The term equal pay for work of equal value has been the common one in Great Britain, Australia and New Zealand, although it is now frequently superceded by the deliberately softer and vaguer term pay equity. Equal value has the advantage (or otherwise!) of bringing into the open major controversies, including the question - what is value? Is price or market value the only meaningful concept, as neoclassicists would assert? Is that the same as value to the employer? Is there a different type of value to be established by gender neutral job evaluation or work value excercises, and to what extent does the market come in to this concept? Pay equity discussions have been extended to ethnic differences, particularly in the United States. While the specific gender related rationales for skill undervaluation do not apply, related issues on the construction of skill are equally applicable in this context.

\section{Initiatives in Each Country}

\section{Australia}

According to most commentators, this is the country in which equal pay for equal value initiatives have made the most impact on the female male earnings gap. This has come about through three decisions in 1969, 1972, and 1974 of the Australian Conciliation and Arbitration Commission. The first required equal pay for equal work, the second that female rates be determined by work value comparisons without regard to gender, and the third set one minimum rate for each classification in an award. The female male ratio for average weekly earnings for full time adult non-managerial employees in the private sector narrowed from $59 \%$ in 1970 to $81 \%$ in 1976 , and had reached $83 \%$ in 1988 (Australia Federal Department of Employment, Education and Training Women's Bureau 1987, National Women's Consultative Council, 1990).

The strong impact of these decisions on the earnings ratio can be attributed to a number of factors, including the wide coverage and wider influence of Commission decisions across the workforce. The combination of heavily centralised wage settlement with comparatively low disparities between male wages in female and male dominated work (discussed later) was critical to this impact. Any negative employment effects were small, at a time of strong demand, particularly for labour in areas of female dominance. 
Nevertheless, pay equity advocates consider that a considerable degree of gender discrimination remains. Allowances, over award and supplementary payments are greater for men. Only $18 \%$ of adult female employees in 35 awards received equal pay for work of equal value through the 1972 decision (NWCC, 1990:10), few work value excercises were carried out (Women's Legal Resources Group, 1985), and those were on the narrow basis of like work. A number of cases have been put to the Commission through the 1980s, during which time wage settlements have been subject to principles agreed under the government/trade union Accord. Flat rate increases during this period have resulted in some relative gains to lower paid groups, including women. The anomalies principle was used successfully by nurses in the Australian Capital Territory to gain increases on the basis that the 1972 decision had not been correctly applied. A Pay Equity Bureau has recently been established within the Federal bureaucracy. The award restructuring process, together with extension of coverage of supplementary payments in some awards, offers the prospect of some further improvements, although progress is likely to be slow.

\section{Canada}

The Federal-State structure has resulted in a more varied approach to pay equity initiatives than in Australia, where pay settlement is more centralised. Complaints based equal pay for work of equal value principles were introduced into human rights codes in Quebec and at federal level as early as 1977 and 1978, with only minor impacts. In 1990 a federal public service pay study concluded that four out of nine female dominated job categories were undervalued, with four others already having received pay equity increases. Five years back pay was to be paid to 70,000 workers in these groups, which included secretary-typists, who would gain a $5.6 \%$ increase from a comparison with printers.

Manitoba and Ontario are the first states in Canada to introduce, in 1985 and 1987, proactive pay equity legislation, recognising systemic gender discrimination in wage setulement. Manitoba covers only the public service, whereas Ontario covers in addition private sector employers, on a mandatory basis for those with 100 or more employees, and on a permissive basis for those with 10 to 99 . Women are, as elsewhere, overrepresented in small firms.

In Ontario, employers and unions are required jointly to negotiate the pay equity plan. For non-unionised employee classes, the employer is obligated to prepare the plan. Complaints over plans can be taken to the Pay Equity Commission, which is responsible for concilation and mediation, in addition to education, information and research. There is also a Pay Equity Hearings Tribunal to hear unresolved disputes. The plan involves comparisons between female job classes (60\% plus female) and male job classes (70\% plus male) using some form of job evaluation within an establishment. Excluded from the comparisons are differences based on skill shortages and training, as well as pay differences resulting from redcircling, seniority and merit pay, provided these have been determined without gender bias.

The Ontario government pay equity plan involves increases averaging $10 \%$ for $96.5 \%$ of 28,500 women in 162 unionised job classes. The increases, paid over three years, are estimated to be $2.5 \%$ of total payroll (Symes, 1990). It is too soon to estimate the impact of private sector increases. Problems which have arisen in the private sector include the availability of suitable comparators, the adequacy of the comparison, and the implementation and maintenance of the plan, which is the responsibility of the employer. Test cases have already occurred over the question of who is the employer, as a narrow defiintion prevents there being suitable male comparator job classes or keep comparisons narrow. The Ontario Nurses Association successfully argued that the Regional Municipality of Haldiman-Norfolk was the employer of the police force, allowing a comparison for nurses with police.

The gender neutrality of major job evaluation systems in particular applications is under challenge from unions. In the first major decision defining the standards needed from used of a gender neutral jobcomparison, "the Tribunal held that the Municipality's bargaining practices and proposed jobevaluation system prepared by the consulting firm William M. Mercer Limited violated the Act and failed to identify and rectify the systemic discrimination in compensation faced by the Union's Public Health and Homes for the Aged nurses" (Cornish 1991:5). The system was held to have failed to accurately describe, value and make visible the work of the nurses, while the employer ignored criticisms of the system and failed to inform itself about the nurses work. (Cornish gives a detailed analysis of the case, in which she appeared.) A second, similar judgement has recently been released with respect to application of the SKEW system in a nursing setting.

\section{Great Britain}

The equal pay law in Great Britain was amended at the beginning of 1984 due to an E.E.C. directive to extend coverage to work of equal value - "in terms of the demands made on a female worker (for instance, under such headings as effort, skill and decision) compared to that of a man in the same employment" (Equal Opportunities Commission 1984:11). Previously a claim could be made for equal pay only for the same or broadly similar work or where equal value had already been established under a proper job evaluation scheme. The legislation is complaints based, with claims for equal pay within a firm made on an individual basis only, naming a male comparator, and investigated by an Independent Expert under the ACAS system. However, some recent cases have led to extensive flow ons to broadly based groups within an industry. 
In defence to a claim, the employer may assert that a 'material factor' accounts for the difference in pay, despite the jobs being of equal value. On the scope of this defence, the Equal Opportunity Commission argued: "It is unclear to what extent factors not personal to the two job-holders (for example commercial or business reasons) will be a justifiable defence once it is established that you are employed on work of equal value and, for example, whether pay differences based on skill shortages could be a genuine material factor (op cit:17/18).

Since then, a considerable number of cases have been through the British tribunals, and the application of the material factor defence appears to have been inconsistent. Progress has been relatively slow, with the Commission and many other groups pressing recently for improvements to the legislation to allow group actions and speed up proceedings. Arguments for a minimum wage have been linked with these proposals. A National Pay Equality Campaign was launched in 1991, and had Labour been elected in 1992, improvements were likely. In the current climate, use of existing legislation will continue to be stepped up. For example in the electricity supply industry the union, NALGO, has annually and unsuccessfully submitted a national claim for a grading structure reflecting equal value principles. Since privatisation, the plan is to take at least one case against each company, targetting clerical positions and making comparisons with industrial grades, in the hope of persuading employers to negotiate. Some large employers in Britain are no longer as opposed to equal value concepts as in the past. Reviews of antiquated pay systems can lead to efficiency gains and better use of all sections of the workforce.

While it was European Economic Community pressure, based on Article 119 and the Equal Pay Directive, which led to the changes to the law in Great Britain, it appears that practical progress on equal pay for work of equal value has been disappointing elsewhere in the EEC, despite the Equal Treatment Directive and the Danfoss case (see Prechal and Burrows, 1990).

\section{New Zealand}

Equal pay for equal work was implemented in the public sector in 1960 and in the private sector by the Equal Pay Act, 1972 which covered remuneration, however determined, and applied to actual rates of pay as well as those prescribed in awards, collective agreements, and other formal instruments (Review Committee, 1979). The Act defined equal pay as a rate of remuneration for work in which rate there is no element of differentiation between male employees and female employees based on the sex of the employees. For work exclusively or predominantly performed by female employees, the Equal Pay Act 1972, Section 3(1) required payment of "the rate of remuneration that would be paid to male employees with the same, or substantially similar, skills, responsibility, and service performing the work under the same, or substantially similar, degrees of effort."
In practice, only narrow comparisons were in fact made, and the Act was only workable with respect to identical work, not the broader equal value which the wording appears toallow (Review Committee, 1979:43, Orr 1986b:7/ 8). Inadequate enforcement of the Act, use of discriminatory job titles, and narrow interpretations by the Arbitration Court were further negative factors (Orr 1986a and b). In individual cases, very broad use of the special qualities clause was regarded as allowable by the Court. For example, the need to match the previously higher pay of a male recruit was regarded as a justifiable reason for paying him above the rate paid to a female employee doing similar work. This virtually legitimates the male female dual labour market.

Nevertheless, the male/female earnings gap was reduced during the implementation period of the Act (1973/77). The ordinary time hourly earnings ratio, which produces the smallest gap since it excludes overtime and hours differences, narrowed from $72.1 \%$ to $78.5 \%$ during this period and is now about $81 \%$. The very slow change after 1977 led in the mid 1980s to dissatisfaction among women's groups and some trade unions.

Consequently the Clerical Workers Union took a case to the Arbitration Court in February 1986, seeking a ruling that their employers should be directed to negotiate on a claim for equal pay for work of equal value. The Court declined jurisdiction. The ruling in essence meant that if awards had been registered during $1973 / 77$, indicating de facto acceptance that they incorporated equal pay, the question could not be reopened (New Zealand Arbitration Court, 1986). Resulting pressure led to government commissioning an Equal Pay Study and finally to new legislation in the form of the shortlived Employment Equity Act, passed and repealed in 1990 (See Hyman et al 1986 for the Equal Pay Study: Wilson, 1992 for an overview of this period).

The pay equity part of the 1990 Act (it also included equal opportunity provisions, with employers above a minimum size being required to lodge plans with a government office) was to involve a two stage process. The first stage allowed unions representing women in a female dominated occupation, one with $60 \%$ or more women employees, to request a pay equity assessment, suggesting both a definition for that occupation and two male comparator occupations ( $60 \%$ or more male). The assessment process was to consider skill, effort, responsibility and working conditions and to recognise differences in remuneration levels attributable to recruitment and retention differences. The report of the assessment would have made judgements on the extent of any gender bias in the remuneration of the female occupation. In the second stage, unions representing some or all workers within the female occupation could make a pay equity claim based on the assessment. It was to be negotiated, but if not settled within 60 days, could be referred by either party for determination by final offer arbitration by the Arbitration Commission. 
The procedure was fairly similar to the British legislation, except that it involved class action, and pay increases in response to a favourable finding were not automatic. The two stage process in the Act arose partly from a unique feature, the cross employer potential. This was sought by pay equity advocates, because of both the occupational basis for the arguments that female dominated work is underpaid and the cross employer award wage system which then applied to much of the female workforce. However, it aroused even more employer, economist and National party ire than within employer comparisons, and would have been hard to implement, particularly as the industrial relations structure was moving towards industry and enterprise bargaining. The Act had resulted from a series of compromises and ended up pleasing nobody. Nevertheless, work had started on a gender neutral job evaluation scheme and claims had been made for some groups prior to repeal..

The National government, elected to power later in 1990 , duly repealed the Act and substantially deregulated the labour market, increasing the relative bargaining power of employers at a time of high unemployment. In this climate, despite provisions inserted into the Employment Contracts Act 1991 to include contracts within the 1972 Equal Pay Act, even equal pay for identical work is uncertain and hard to enforce. High unionisation and the previous methods of wage settlement were in New Zealand, as in Australia, factors contributing to the relatively lower earnings gap compared with the United States. While the government claims that deregulation favours women, it is clear that part time and casual work is growing rapidly, differentials are widening, and women and Maori, concentrated in lower paid areas, defined as less skilled, will be the major losers (Harbridge 1991, Novitz and Jaber 1991).

\section{United States}

The most major developments have taken place at state and in some cases local government level, often through the use of policy capturing job evaluation studies (Hyman, 1988). Implementation of plans to rectify the gender biases identified have varied in their completeness. Issues include political and financial horse trading with regard to quanta and phasing, the appropriate pay line and protection for other workers. Changes may in some cases remedy only the obvious gender gap, not the other equity and efficiency issues indicated by what has been shown to be valued by the statistical study (Steinberg 1987).

In the private sector, collective bargaining and restructuring of pay structures by some firms has allowed a degree of progress, with support from the National Committee on Pay Equity (NCPE 1990) but the legal support provided by the Equal Pay Act and Title VII of the Civil Rights Act is minimal.

\section{The Female-Male Earnings Gap}

There is a large econometrically based literature, especially in the US, fitting earnings functions and attempting to decide what proportion of the relevant earnings gap is due to differences in human capital endowments and what proportion to difference in coefficients or returns to those endowments. Some empirical studies argue that more of the gap is attributable to lower returns, found whether women are in male or female dominated occupations (Aldrich and Buchele, 1986).

Earnings function studies do not, of course, yield unchallengeable answers to the extent of even direct wage discrimination, let alone overall discrimination. Some neoclassical economists believe that the human capital measures, such as years of education and experience. are too crude to pick up all the productivity differences. In addition, they argue that occupational crowding and industry/enterprise differences in ability to pay may mean that lower returns for women to human capital vanubles are not necessarily discriminatory. However, the force of this is diminished for comparisons within the workforce of an individual employer.

For pay equity advocates, the wage discrimination found in earning functions studies are minimal estimates of overall discrimination. The definition and evaluation of skills are partially at least social constructs rather than objective measures. If skills needed in many women dominated occupations are undervalued, and training acquired in work at home is seen as needing no economic return, then pay in such occupations will be lower than productivity factors would indicate. There is a large literature on skill analysis which supports these views (for example Cockburn 1983, Hill and Novitz 1985, Wood, 1986).

There are also monopoly elements on both sides of most labour markets. Collective bargaining can result in trade unions or employer groups with greater degrees of power than others affecting the theoretically determined relative wage rates in a manner favourable to their interests, which will not usually be those of women. Adjustment processes are slow. Thus institutional factors, horizontal and vertical occupational segregation, and discrimination in the assessment of skill, rather than the simple operation of supply and demand factors, are major determinants of the earnings gap. It is argued that this remains true even (perhaps especially!) in a more deregulated labour market environment.

Average female earnings and incomes are below those of males in all countries, but the extent of the gap is very variable and care must be taken with comparisons because of definitional and data differences. However, for the five countries considered here, the gap is widest in the United States and narrowest in Australia. Great Britain is probably closest to the U.S. and New Zealand to Australia, Canada's position being around the middle. 
The use of the gap in average earnings and/or its rate of change as an index of gender discrimination is of course problematic. The issues discussed above with respect to earnings functions studies are confounded by averaging over the entire labour force. Changes in the average gap can arise partly from structural differences, such as growing female labour force participation altering the average experience of females employed, as well as changes in the gap at micro level. Equating pay levels for comparable workat the micro level is the target for pay equity initiatives. Successes at this level will narrow the overall gap, ceteris paribus. So will gradual change and/or equal opportunity initiatives which result in women being employed at higher levels in higher paid previously male dominated types of work. Thus disentangling changes to the average gender earnings gap is complex. Nevertheless it is a broad brush indicator of some use, and can be a starting point for disaggregation. Studies of this type are dicussed later.

It is beyond the word limit for this paper to classify in detail each of the five countries at various times on the criteria of $A$, and readers may enjoy doing this themselves. The discussion of each country indicates where each fit on most of the typologies of B. Clearly the classifications on A affect what is possible and acceptable under B. The discussion to date suggests that the climate factors thus both directly and indirectly have greater impact on the results than the details under B - although differences there are not insignificant. Further comments on factors influencing female and male earnings and their gap will add support to this conclusion.

The effect which occupational and industrial segregation has on pay levels overall and particularly in femaledominated areas is less easy to document unequivocally than the phenomenon itself (see Hawke, 1991, for a discussion of the statistical complexities). There is considerable evidence that female-dominated occupations tend to be generally low paying, and particularly so for women. Gregory, Daly and Ho (1986) found that femaledominated/male-dominated and mixed occupations had weekly female/male earnings ratios of $73.5 \%, 80.3 \%$ and $74.1 \%$ respectively in Britain, and $74.2 \%, 87.9 \%$ and $77.6 \%$ in Australia. The overall ratios were $62.9 \%$ in Britain and $75.3 \%$ in Australia (op cit:Table 4). In both countries the gap was wider in female dominated occupations, which also yield much lower absolute levels of female earnings. However, there is one important additional difference between the two countries. This is the very much lower level of male earnings in femaledominated occupations in Britain. They averaged $96.2 \%$ of the male overall average in Australia, as against $82.0 \%$ in Britain. The higher male wage in female occupations in Australia helps pull up female wages there and perhaps elsewhere.

Gregory has also compared Australian and United States experience, applying the coefficients of the earnings functions in each country to the structure in the other.

\section{Climates for Progress on Pay Equity and Typologies of Initiatives - Classification and Assessment of Relative Importance}

The following classifications are useful in considering the relative importance of different factors in reducing gender labour market discrimination, including but not limited to pay equity initiatives:

\section{A. Climate for Progress on Pay Equity (Interrelated factors)}
A1
Economic situation
A2
Occupational and industrial segregation/ structure of pay by occupation, industry, enterprise, gender (and ethnicity)
A3 Systems of pay settlement/ industrial relations law and practice
A4 Political climate/ philosophy

\section{B. Typologies of Initiatives}

B1

B2

B3

B4
Structures - Legislation/ Industrial Tribunal/ Administrative decision/ Collective bargaining/Individual bargaining

Breadth of coverage - complaints based $v$ general/ public sector $v$ public plus private (size limit?)/ individual $v$ group

Comparison methods - Policy capturing job evaluation/ a priori job evaluation scheme/ ad hoc method

Comparison groups - across employer $\mathrm{v}$ within/ across what occupation groups/ definitions of female, male, mixed occupations/ criteria for comparators/ issues of lack of comparators 
Within each country, human capital factors can account for about half of the female male eamings gap. However, the much greater reduction and resulting smaller size of the gap in Australia cannot be explained by differences in industry mix or human capital endowments (Gregory et al, 1989). Thus it appears that the institutional factors discussed above for Australia, contrasting with the deregulated market in the United States, have been the most important influence. Overall, the research, analysis, and feminist efforts in pay equity have been most extensive in the US for the least effect, apart from some public sector jurisdictions.

Of course, these comparisons simply pose more questions about the factors which brought about the structural differences. Another example is the issue of why New Zealand has retained minimum wage but not pay equity legislation with the advent of a National government, when the reverse situation applies in Great Britain with a government of a similar hue.

Despite the conclusion that the climate is more important than the detail of the pay equity measures, some provisions have more widespread results than others. The Ontario legislation, with its proactive nature, provides the most interesting prospect. It is currently being amended to provide for female job classes with no obvious comparators. Other areas needing attention are non unionised workplaces and progress on gender neutral job evaluation.

While collective bargaining and group action may on their own lead to pay equity settlements, some type of job evaluation is involved in most attempts to implement equal pay for work of equal value, whether through policy capturing or a priori schemes. They at least make explicit and open for discussion the judgements which may otherwise be only implicit. A variety of studies have found that female-dominated occupations are underpaid, and the extent of this is understated in those which fail to avoid gender bias. (Treiman and Hartmann 1981, Wisconsin Task Force 1985). The literature on gender bias in job evaluation schemes now includes welcome attempts to construct improved schemes (Burton et al 1987, Equal Opportunities Commission 1985, Hastings 1991, Hyman 1988, Burns and Coleman 1991, Steinberg 1987).

Another issue of importance is the breadth and nature of comparisons between jobs allowed under legislation and its administration. If they are only possible between very similar jobs, the undervaluation of traditionally femaledominated occupations cannot be addressed, particularly if male wages in such occupations are depressed close to the low female level. Where there is a large variety of types of work within a single employer's jurisdiction, such as at U.S. state government level, this is automatically secured. In Australia, the relative homogeneity of male wages meant that the need for comparisons across occupations was less crucial in raising female rates.

\section{The Future of the Earnings Gap and Pay Equity in New Zealand}

The lessons from New Zealand experience are salutary. It is easy to lose battles previously won, particularly in a small country with a unitary structure of government where total policy reverses led by a small group have few barriers to overcome. The 1990 legislation may also have been somewhat too ambitious and complex. In the current economic and industrial relations climate, the ongoing effectiveness and practability of enforcement of the Equal Pay Act, even for identical work, is in doubt. There are considerable problems in defining, assessing and countering gender discrimination under current legislation and the associated economic climate/ power distribution.

With individual contracts becoming more common, and earnings likely to be more varied by region, industry, firm and other factors, the problems of establishing discrimination in individual cases mentioned earlier will apply to a greater proportion of the workforce than before. The greater earnings variation will make even more difficult the isolation of a gender factor (or make it easier to cover up). Collective contracts will on average cover less workers. Less people are in a position to know what others are paid, and thus whether there is any discrimination. Only collective contracts with over 20 people covered have to be lodged, and access to this information is uncertain. More general moves to privacy of remuneration information, including positions on scales and merit pay, can mask discrimination. Women, especially those in small workplaces, are likely to be reticent about making enquiries and complaints. This may be due to socialisation and/or from understandable fears of retaliation or unpleasantness from the employer or male fellow workers, and of long delays in securing an outcome. These fears will be greater with high levels of unemployment, a climate where the employer has more bargaining power, and 6 month benefit stand down periods after voluntarily leaving a job or being dismissed. These considerations raise the urgent need for gender specific information on contract and earnings outcomes: surveys to date since the Employment Contracts Act are totally inadequate.

Merit and performance pay is becoming more common, and despite the efficiency and equity cases which can be made in its favour, it provides considerable potential for unintended gender discrimination (Burton, 1987 and 1988).

Thus the gender earnings gap is quite likely to widen again. Factors countering this are any results from voluntary equal opportunity initiatives and/or gradual progress of women in the labour force. The minimum wage, although unchanged for some years, may also mitigate the problem in a period of low inflation, as well as hopefully reducing exploitation of over 20 year old lower paid workers, predominantly Maori and women. However, these points are likely to be outweighed by the counter pressures, exacerbated by the general widening of differentials and the trend to part time and casualised work, with women 
concentrated in these areas. New Zealand's practical adherence to ILO Convention 100 on Equal Pay for Work of Equal Value, which it has ratified, may rightly come under increasing question.

\section{Summary and Conclusions}

The success of pay equity initiatives have been tentatively assessed to be more dependent on favourable prevailing economic, political and industrial relations climates and philosophies than the detail of the initiatives. The level and rate of reduction of the genderearnings gap, while a highly imperfect measure of progress in the elimination of discrimination against women in the labour market, has some uses as a broad brush indicator. A number of factors make it likely that the gap will widen again in New Zealand under current policies, and this is disturbing. The factors include problems in isolating and measuring discrimination in a contract environment, particularly with the wording and previous interpretations of the Equal Pay Act.

\section{Future Research}

Issues in the area which would benefit from further research include:

a. Qualitative research on differences between the countries in the climate and in the literature/debates on discrimination, the male female earnings gap, and the merits/problems of pay equity initiatives.

b. Collection and analysis of contract and earnings data in New Zealand by gender, industry, occupation and other profile data, including estimation of earnings functions.

3c. Case study collection of data within a number of large enterprises on remuneration decision making and outcomes - including placement on scales and merit/ performance pay: analysis is to include gender effects.

\section{References}

Acker, J. 1989 Doing Comparable Worth-Gender, Class, and Pay Equity Temple University Press, Philadelphia

Aldrich, M. and R. Buchele 1986 The economics of comparable worth Ballinger Publlishing Company, Cambridge, Massachusetts

Australia Conciliation and Arbitration Commission 1986 Judgement by Mr Justice Madden, President PO55CR M.S. 067/86MD Print G 2250, Canberra

Australia Federal Department of Employment, Education and Training Women's Bureau 1987 Pay Equity - a Survey of 7 OECD Countries Information Paper no 5, Canberra
Bose, C and G.Spitze (eds) 1987 Ingredientsfor Women's Employment Policy State University of New York Press, New York

Brenner, J. 1987 Feminist Political Discourses: Radical Versus Liberal Approaches to the Feminization of Poverty and Comparable Worth Gender and Society $1 / 4: 447-465$

Burns, J and M. Coleman 1991 Equity at Work - an Approach to Gender Neutral Job Evaluation State Services Commission and Department of Labour, Wellington

Burton, C. 1987 Merit and gender. organisations and the mobilisation of masculine bias Australian Journal of Social Issues 22/2:424-435

Burton, C. 1988 Redefining merit Affirmative Action Agency, Monograph No 2, Commonwealth of Australia, Canberra

Burton, C with Hag, R and G. Thompson 1987 Women's Worth-Pay Equity and Job Evaluation in Australia AGPS Press, Canberra

Cockburn, C. 1983 Brothers - Male Dominance and Technological Change Pluto Press, London

Cornish, M. 1991 Standards for Making Visible and Positively Valuing Women's Work - Review of Jurisprudence under Ontario's Pay Equity Act paper to Conference on Pay Equity, London

Cuneo, C. 1990 Pay Equity - the Labour-Feminist Challenge Oxford University Press, Toronto

Equal Opportunities Commission 1984 Equal Payfor Work of Equal Value - A Guide to the Amended Equal Pay Act Equal Opportunities Commission, Manchester

Equal Opportunities Commission 1985 Job Evaluation Schemes Free of Sex Bias Equal Opportunities Commission, Manchester

Evans, S and B. Nelson 1989 Wage Justice: Comparable Worth and the Paradox of Technocratic Reform University of Chicago Press, Chicago

Gregory, R. Anstie, R. Daly, A and V.Ho 1989 Women's Pay in Australia, Britain and the United States: the Role of Laws, Regulations and Human Capital in Pay Equity - Empirical Inquiries, Michael, R. Hartmann, H and B.O'Farrell (eds), National Academy Press, Washington, D.C.:222-242.

Gregory, R. Daly, A and V. Ho 1986 A Tale of Two Countries: Equal Pay for Women in Australia and Britain Discussion Paper No. 147 Australian 
National University, Centre for Economic Policy Research, Canberra

Harbridge, R. 1991 Collective bargaining and the Employment Contracts Act: social policy implications paper to National Social Policy Conference, Wellington

Hartmann, H. (ed) 1985 Comparable Worth: New Directions for Research National Academy Press, Washington, D.C.

Hastings, S. 1991 Developing a Less Discriminatory Job Evaluation Scheme Technical Note No. 109 Trade Union Research Unit, Ruskin College, Oxford

Hawke, A. 1991 Male-Female Wage Differentials: How Important is Occupational Segregation? Discussion Paper No. 256 Australian National University Centre for Economic Policy Research, Canberra

Hill, R and R. Novitz 1985 Class, Gender and Technological Change paper to New Zealand Sociological Association Conference.

Hyman, P. 1987 The Fight for Equal Pay for Work of Equal Value (Comparable Worth) in New Zealand - Lessons from Past Campaigns in New Zealand and Elsewhere paper to Seventh Berkshire Conference on the History of Women

Hyman, P. 1988 Equal Pay for Work of Equal Value - Job Evaluation Issues New Zealand Journal of Industrial Relations 13:237-255

Hyman, P. Neale, J. and Urban Research Associates 1987 Equal Pay Study - Phase One Report New Zealand Department of Labour, Wellington

National Committee on Pay Equity 1990 Bargaining for Pay Equity - a Strategy Manual National Committee on Pay Equity, Washington, D.C.

National Women's Consultative Council 1990 Pay Equity for Women in Australia Labour Research Centre, Melbourne

New Zealand Arbitration Court 1986 Oral decision of the Court delivered by Finnigan, J., (A.C. 24/86 D.I. 176/85), Wellington

Novitz, R du Plessiz and N. Jaber 1990 Pay Equity, the "Free" Market and State Intervention" New Zealand Journal of Industrial Relations 15: 251-262

Orr, E. 1986a The Arbitration Court's Role in Supervising the Equal Pay Act 1972 Centre for Continuing Education, Victoria University, Wellington
Orr,E. 1986b The EqualPaySceneRevisited unpublished paper

Prechal, S and N. Burrows 1990 Gender Discrimination Law of the European Community Dartmouth Press, Aldershot

Reskin, B. 1988 Bringing the Men Back In: Sex Differentiation and the Devaluation of Women's Work Gender and Society 2/1:58-81

Review Committee 1979 Equal Pay Implementation in New Zealand Department of Labour, Wellington

Steinberg, R. 1987 Dilemmas of Advocacy Research: Experiences with Comparable Worth paper to plenary panel of Social Science Research and Law Reform, Law and Society Association

Symes, B. 1990 Pay Equity in Canada paper for 8th Annual Labour Arbitration Conference Calgary, Alberta

Treiman, D. and H. Hartmann (eds) 1981 Women, work and wages: equal pay jor jobs of equal value National Academy Press, Washington D.C.

Wisconsin Task Force on Comparable Worth 1985 Report University of Wisconsin, Madison

Wood, S. 1986 Work Organisation in Work, Culture and Society Deem, R. (ed) Oxford Unversity Press, Oxford

Wilson, M. 1992 Employment Equity Act 1990: a Case Study in Women's Political Influence, 1984-90 in Controlling Interests - Business, the State and Society in New Zealand, Deeks, J. and N. Perry (eds) Auckland University Press, Auckland

Women's Legal Resources Group 1985 She works hard for the money ... Equal Pay for Women Women's Legal Resources Group, Victoria 